\title{
The relation between of insulin like growth factor II and endometrial carcinoma
}

\author{
Hossam Hassan El Sokkary ${ }^{1 *}$, Doaa Ibrahim Hashad ${ }^{2}$, Ahmed Nooman Sallam¹, \\ Amal Zaky Azzam', Mohamed Ebied Abo Koura'
}

\begin{abstract}
${ }^{1}$ Department of Obstetrics and Gynecology, Faculty of Medicine, Alexandria, Egypt
${ }^{2}$ Department of Clinical Pathology, Faculty of Medicine, Alexandria, Egypt
\end{abstract}

Received: 12 December 2019

Revised: 27 December 2019

Accepted: 03 January 2020

\section{*Correspondence:}

Dr. Hossam El Sokkary,

E-mail: hossamsokkary@hotmail.com

Copyright: () the author(s), publisher and licensee Medip Academy. This is an open-access article distributed under the terms of the Creative Commons Attribution Non-Commercial License, which permits unrestricted non-commercial use, distribution, and reproduction in any medium, provided the original work is properly cited.

\begin{abstract}
Background: Endometrial cancer is the most common gynecologic malignancy in the United States and the fourth most common cancer in women. The need of a soft marker that can be used with CA-125 tumor marker for early detection of endometrial cancer and to predict late stages and advanced histopathological grades and to specify the cases who will be managed by complete surgical staging including para aortic and pelvic lymphadenectomy is of great importance. The aim of the study was to evaluate the role of insulin like growth factor 2 in endometrial carcinoma and to correlate it with different histopathological grades of the disease.

Methods: This study was applied on sixty patients with abnormal uterine bleeding and were divided into two groups, Group A included 30 cases of endometrial carcinoma, while Group B included 30 cases complaining of abnormal vaginal bleeding due to other causes as a control group. Serum samples were taken from all patients and estimation of IGF-2 serum levels using ElISA technique was done. Comparison of IGF-2 serum level between both groups and correlation of its levels with different histopathological grades of endometrial cancer group were done.

Results: As regard comparison between both groups and ILGF2 serum level, study results demonstrated that ILGF2 levels ranged between $600.0-1440.0 \mathrm{ng} / \mathrm{ml}$ and $40.0-560.0 \mathrm{ng} / \mathrm{ml}$ with the mean of $781.33 \mathrm{ng} / \mathrm{ml} \pm 196.45$ and 336.0 $\mathrm{ng} / \mathrm{ml} \pm 212.86$ for cases Group A and control Group B respectively. There was a statistically significant difference between the two studied groups regarding ILGF2 serum level $(p<0.001)$. As regards correlation between histopathological grades and ILGF-2 serum level in cases Group A, the study revealed a strong positive correlation.

Conclusions: ILGF-2 can be used as a serum marker for endometroid adenocarcinoma of the body of the uterus and to predict its higher histopathological grades.
\end{abstract}

Keywords: Endometrial cancer, Insulin like growth factor 2

\section{INTRODUCTION}

Endometrial cancer is the most common gynecologic malignancy in the United States and the fourth most common cancer in women, the American Cancer Society estimated that there were 47,130 new cases of endometrial cancer and 8,010 deaths from endometrial cancer in 2012. ${ }^{1}$ In developing countries as in Egypt, it ranks the second after cancer cervix. ${ }^{2}$ The need of a soft marker that can be used with CA-125 tumor marker for early detection of endometrial cancer and to predict late stages and advanced histopathological grades and to specify the cases who will be managed by complete surgical staging including para aortic and pelvic lymphadenectomy is of great importance. ${ }^{3}$ Insulin-like growth factor 2 (IGF-2) is a protein hormones that is 
similar structurally to insulin. It is synthesized by the liver and characterize by a growth-regulating insulin-like mitogenic properties. ${ }^{4}$ Over production of growth factors and/or their receptors is very common in malignancy and may be the cause of uncontrolled proliferation that happen in malignancy. The IGF-2 expression is strictly regulated and any changes that affect the particular balance of the system can trigger a number of molecular events that can lead to malignancy. ${ }^{5}$ Many studies have documented the role of the IGF system in malignancy and development of neoplasm of different cell types, many malignancies have been shown to over synthesize the IGF-2 and/or IGF-2 receptor. ${ }^{6}$ In endometrium, many studies document the role of IGF-2 as a mediator of estrogen function through paracrine/autocrine mechanisms, and its overproduction may be associated with endometrial cancer. ${ }^{7}$ The IGF- 2 mRNA levels have a high level in cancer cells and cancer-adjacent cells, suggesting that IGF-2 may be an important factor for transforming normal cells into neoplastic cell. This finding suggest that IGF-2 can be the stimulus of cancer development through autocrine mechanism, that's why authors need to study IGF-2 effects in vivo in endometrial cancer. The aim of the study is to evaluate the role of insulin like growth factor 2 in endometrial carcinoma and to correlate it with different histopathological grades of the disease.

\section{METHODS}

Following approval by our institutional ethics committee, an observational prospective controlled study was done for patients attending gynecology outpatient clinic in Shatby Maternity University hospital from August 2011 to December 2014 with perimenopausal uterine bleeding and endometrial thickness more than $16 \mathrm{~mm}$, failed medical treatment in perimenopausal uterine bleeding and endometrial thickness less than $16 \mathrm{~mm}$, post-menopausal uterine bleeding and endometrial thickness more than 4 $\mathrm{mm}$ in patients and post-menopausal bleeding and endometrial thickness less than $4 \mathrm{~mm}$ in patients with risk factors as non-hormonal replacement therapy users, more than one attack, fluid in the cavity. ${ }^{8}$ Patients enrolled in the study, were explained at first the procedure which was done and a written informed consent was taken from them. Dilatation and curettage and endometrial biopsy was taken followed by histopathological examination from all patients who were categorized into two groups according to histopathological results, Group A (cases group) included 30 cases of endometrial carcinoma of any histopathological types while Group B (control group) included 30 cases complaining of abnormal vaginal bleeding due to other causes as endometrial hyperplasia, atrophic endometrium, or other benign causes as intake of hormonal replacement therapy, endometrial polyps, submucous leiomyomas. Exclusion criteria for both groups were diabetes mellitus, marked obesity (body mass index $\geq 40$ ), endocrine diseases, hepatitis as all of them affect ILGF-2 serum level. Serum samples were taken from all patients and estimation of
IGF-2 serum levels using ElISA technique was done. Comparison of IGF-2 serum level between both groups and correlation of its levels with different histopathological grades of endometrial cancer group were done.

\section{Statistical analysis}

Data were fed to the computer and analyzed using IBM SPSS software package version 20.0. Quantitative data were described using median, minimum and maximum, mean and standard deviation and median. For normally distributed data, comparison between cases and control were done using independent t-test. For abnormally distributed data, comparison between cases and control were done using Mann Whitney test while Kruskal Wallis test was used to compare between different groups. Correlations between two quantitative variables were assessed using Spearman coefficient significance of the obtained results was judged at the $5 \%$ level.

\section{RESULTS}

Histopathological examinations of the endometrial biopsy from endometrial cancer cases Group A revealed that's all the 30 patients were endometroid adenocarcinoma, considering their histopathological grades 13 (43.3\%) out of 30 cases were of grade 1, 10 of the cases $(33.3 \%)$ were of grade 2 and 7 of the cases $(23.3 \%)$ were of grade 3 as shown in Table 1 .

Table 1: Distribution of cases Group A according to histological grade $(n=30)$.

\begin{tabular}{|lll|}
\hline \multicolumn{2}{|c|}{ Numbers of cases } & Percentage \\
\hline Histological grade & \\
\hline Grade 1 & 13 & $43.3 \%$ \\
\hline Grade 2 & 10 & $33.3 \%$ \\
\hline Grade 3 & 7 & $23.3 \%$ \\
\hline
\end{tabular}

While histopathological examinations of the endometrial biopsy from control Group B which included 30 patients with abnormal uterine bleeding due to non-malignant causes were distributed as follows: 13 cases were simple endometrial hyperplasia, 10 cases were atrophic endometrium, 6 cases were proliferative endometrium, and 1 case was proliferative endometrium with submucous myoma as shown in Table 2.

\section{Table 2: Different histopathological result of control} Group B.

\begin{tabular}{|ll|}
\hline Histopathological result & Numbers of cases \\
\hline Simple endometrial hyperplasia & 13 \\
\hline Atrophic endometrium & 10 \\
\hline Proliferative endometrium & 6 \\
\hline $\begin{array}{l}\text { Submucous myoma with } \\
\text { proliferative endometrium }\end{array}$ & 1 \\
\hline
\end{tabular}


As regard comparison between both groups and ILGF2 serum level, Table 3 demonstrates that ILGF2 levels ranged between $600.0-1440.0 \mathrm{ng} / \mathrm{ml}$ and 40.0-560.0 $\mathrm{ng} / \mathrm{ml}$ with the mean of $781.33 \mathrm{ng} / \mathrm{ml} \pm 196.45$ and 336.0 $\mathrm{ng} / \mathrm{ml} \pm 212.86$ for cases Group A and control Group B respectively. There was a statistically significant difference between the two studied groups regarding ILGF2 serum level $(\mathrm{p}<0.001)$. As regards correlation between histopathological grades and ILGF-2 serum level in cases Group A, authors found a strong positive correlation, as ILGF-2 serum levels ranged between $600.0-680.0 \mathrm{ng} / \mathrm{ml}, 720.0-880.0 \mathrm{ng} / \mathrm{ml}$ and $920.0-1440.0$ $\mathrm{ng} / \mathrm{ml}$, with the mean of $624.62 \mathrm{ng} / \mathrm{ml} \pm 26.02,792.0$ $\mathrm{ng} / \mathrm{ml} \pm 52.66$ and $1057.14 \mathrm{ng} / \mathrm{ml} \pm 197.12$ for histological grades 1, 2 and 3 respectively as shown in Table 4 and Figure 1, This strong positive correlation between the serum level of ILGF-2 in cases Group A and the grade of differentiation of endometrial carcinoma mean that high serum level of ILGF-2 was associated with higher and poorer histopathological grade.

Table 3: Comparison between the studied groups according to ILGF-2 serum level.

\begin{tabular}{|c|c|c|c|c|}
\hline ILGF2 level & Cases $(n=30)$ & Control (n=30) & $\mathbf{Z}$ & p value \\
\hline Min.-Max. & $600.0-1440.0$ & $40.0-560.0$ & \multirow{3}{*}{$6.672 *$} & \multirow{3}{*}{$<0.001 *$} \\
\hline Mean \pm SD & $781.33 \pm 196.45$ & $336.0 \pm 212.86$ & & \\
\hline Median & 740.0 & 440.0 & & \\
\hline
\end{tabular}

Z: Z for Mann Whitney test; *: Statistically significant at $\mathrm{p} \leq 0.05$.

Table 4: Correlation between histological grades and ILGF-2 levels in cases group.

\begin{tabular}{|c|c|c|c|c|c|}
\hline \multirow{2}{*}{ ILGF2 level } & \multicolumn{3}{|c|}{ Histological grade } & \multirow{2}{*}{${ }^{\mathrm{kW}} \chi^{2}$} & \multirow{2}{*}{ p value } \\
\hline & Grade $1(n=13)$ & Grade $2(n=10)$ & Grade $3(n=7)$ & & \\
\hline Min.-Max. & $600.0-680.0$ & $720.0-880.0$ & $920.0-1440.0$ & \multirow{3}{*}{$25.689^{* * *}$} & \multirow{3}{*}{$<0.001^{* * *}$} \\
\hline Mean \pm SD & $624.62 \pm 26.02$ & $792.0 \pm 52.66$ & $1057.14 \pm 197.12$ & & \\
\hline Median & 640.0 & 800.0 & 960.0 & & \\
\hline Sig. bet. grads & \multicolumn{3}{|c|}{$\mathrm{G} 1-\mathrm{G} 2^{* * *}, \mathrm{G} 1-\mathrm{G} 3^{* * *}, \mathrm{G} 2-\mathrm{G} 3^{* *}$} & & \\
\hline $\mathbf{r}_{\mathrm{s}}(\mathbf{p})$ & \multicolumn{3}{|c|}{$0.941^{*}(<0.001)$} & & \\
\hline
\end{tabular}

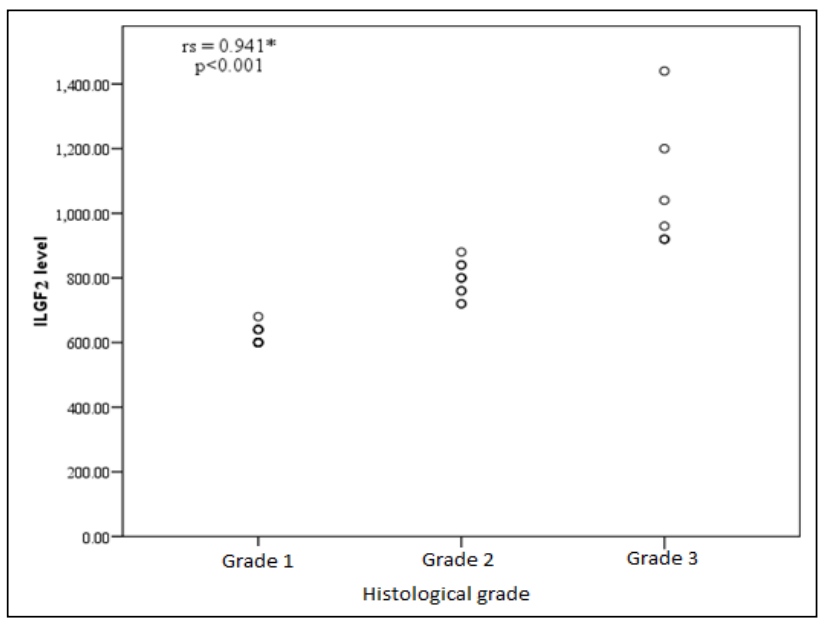

Figure 1: Correlation between histological grades and ILGF-2 serum levels in cases group.

\section{DISCUSSION}

Incidence of endometrial cancer was increased in recent decades, more over the relatively high mortality rate suggests that prevention and/or early detection are an important approach to prevent mortality caused by endometrial cancer. ${ }^{9}$ The need of a specific and sensitive marker that can act with CA125 tumor marker to detect early stages of endometrial is of great importance and can help in its management and to decrease endometrial cancer related mortality. Insulin-like growth factor 2 (IGF-2) is a protein hormone known to regulate cell proliferation, growth, migration, differentiation and survival. ${ }^{10}$ Many studies as $\mathrm{Wu} \mathrm{W}$ et al studied the role of ILGF-2 in endometrial cancer but omitted its serum level correlation with histopathological grades, so authors investigated its serum level with endometrial cancer in a controlled prospective study and correlate its level with different histopathological grades. ${ }^{11}$ This study included 30 patients with endometrial carcinoma in different grades as evidenced by histopathology (cases group) and 30 patients with abnormal uterine bleeding proved not to have endometrial carcinoma (control group). This study showed that there was a significant difference of ILGF-2 serum level between both groups $(\mathrm{p}<0.001)$ and its level demonstrated a positive strong correlation with histopathological grades in endometrial cancer group 
$(p<0.001)$. In agreement with the present study, Petridou E et al, found that the mean plasma levels of IGF-2 were significantly higher in women with endometrial carcinoma versus controls $(670 \mathrm{ng} / \mathrm{ml}$ versus $380 \mathrm{ng} / \mathrm{ml}$, $\mathrm{p}<0.001) .{ }^{12}$ Furthermore, Wang CF et al, reported that ILGF-2 were associated with increased risk of endometrial carcinoma in their study that investigated the effects of ILGF-2 in endometrial cancer cell line. ${ }^{13}$ In disagreement with the present study, Rutanen EM et al, compared 32 endometrial carcinoma patients with 18 non-cancer patients and found lower ILGF-2 levels among endometrial carcinoma patients. ${ }^{14}$ One explanation for this discordance is non exclusion of metabolic or hepatic diseases in cases or control that could affect the serum level of ILGF-2. The main weakness in this study that cases group did not include other pathological types of endometrial cancer as papillary serous types or clear cell types but only endometroid type, so authors recommend to increase cases number so the probability to include other pathological types is increased. From all the above authors can conclude that authors can use ILGF-2 as a useful marker to predict uterine endometroid adenocarcinoma in patients with abnormal uterine bleeding and to expect high histopathological grades if associated with high serum level of ILGF-2 more than $1000 \mathrm{ng} / \mathrm{ml}$

\section{CONCLUSION}

ILGF-2 can be used as a serum marker for endometroid adenocarcinoma of the body of the uterus and to predict its higher histopathological grades.

\section{Funding: No funding sources}

Conflict of interest: None declared

Ethical approval: The study was approved by the Institutional Ethics Committee

\section{REFERENCES}

1. Siegel R, Naishadham D, Jemal A. Cancer statistics, 2012. CA Cancer J Clin. 2012;62:10-29.

2. Siegel RL, Miller KD, Jemal A. Cancer statistics, 2016. CA Cancer J Clin. 2016;66:7.

3. Jiang $\mathrm{T}$, Huang L, Zhang S. Preoperative serum CA125: a useful marker for surgical management of endometrial cancer. BMC Cancer. 2015;15:396.

4. Pickard A, McCance DJ. IGF-binding protein 2 oncogene or tumor suppressor? Front Endocrinol (Lausanne). 2015;6:25.

5. Livingstone C. IGF2 and cancer. Endocr Relat Cancer. 2013;20(6):R321-39.
6. Tian F, Yourek G, Shi X, Yang Y. The development of Wilms tumor: from WT1 and microRNA to animal models. Biochim Biophys Acta. 2014;1846(1):180-7.

7. Geva, Zohar, Bentov, Itay and Fishman, Ami and Werner, Haim and Bruchim, Ilan. (Insulin-like growth factor-I receptor inhibition by specific tyrosine kinase inhibitor NVP-AEW541 in endometrioid and serous papillary endometrial cancer cell lines. Gynecol Oncol. 2011;121:383-9.

8. American College of Obstetricians and Gynecologists. ACOG Committee Opinion No. 426: The role of transvaginal ultrasonography in the evaluation of postmenopausal bleeding. Obstet Gynecol. 2009;113(2 Pt 1):462-4.

9. Ferlay J, Parkin DM, Steliarova-Foucher E. Estimates of cancer incidence and mortality in Europe in 2008. Eur J Cancer. 2010;46:765-81.

10. Sacco A, Morcavallo A, Pandini G, Vigneri R, Belfiore A. Differential signaling activation by insulin and insulin-like growth factors I and II upon binding to insulin receptor isoform A. Endocrinol. 2009; 150:3594-602.

11. El Kafrawy NA, Glal AZ, Kandil MA, Eldin Dawood AA, Essa ES, Elgendy DS. A study of the relation between insulin resistance, insulin-like growth factor-1, and malignancy in type 2 diabetic patients. Menoufia Med J. 2015;28:494-502.

12. Bruchim I, Sarfstein R, Werner H. The IGF Hormonal Network in endometrial cancer: functions, regulation, and targeting approaches. front endocrinol (Lausanne). 2014;5:76.

13. Wang CF, Zhang G, Zhao LJ, Li XP, Qi WJ, Wang $\mathrm{JL}$, et al. Effects of insulin, insulin-like growth factor-I and -II on proliferation and intracellular signaling in endometrial carcinoma cells with different expression levels of insulin receptor isoform A. Chin Med J. 2013;126(8):1560-6.

14. Merritt MA, Strickler HD, Einstein MH, Yang HP, Sherman ME, Wentzensen N, et al. Insulin/IGF and sex hormone axes in human endometrium and associations with endometrial cancer risk factors. Cancer Causes Control. 2016;27(6):737-48.

Cite this article as: El Sokkary HH, Hashad DI, Sallam AN, Azzam AZ, Koura MEA. The relation between of insulin like growth factor II and endometrial carcinoma. Int J Reprod Contracept Obstet Gynecol 2020;9:2310-3. 